\title{
The international politics of food security: How to conciliate global health guidelines for massive food production with fair trade in the third world?
}

\author{
Tatiana Waisberg* \\ Dom Helder College, Brazil
}

\begin{abstract}
This paper explores the interplay of global public health guidelines to both shape food security policy for the third world and promote free trade of commodities. The massive food production system rather than a facilitator to the eradication of hunger contributes to major human rights and environmental violations. As a by-product of a broad human security agenda, the notion of food security may not be dissociated from fair trade imperatives. By targeting the eradication of poverty in all its forms and dimensions, the UN 2030 Agenda for Sustainable Development enhances a multidisciplinary scope, transforming the relationship among individuals, communities, states, international organizations and non-state actors, such as NGO's and private companies. Against this background, the main argument investigates whether the institutionalization of global public health operates as a major obstacle to promote food security in the third world.
\end{abstract}

Keywords: Food security, Public health, Food industry, International law, Fair trade, Commodities.

Accepted on July 13, 2018

Abbreviations: TWAIL: Third World Approaches to International Law

\section{Introduction}

The struggle against extreme poverty, hunger and malnutrition informs the notion of food security enhanced at the UN 2030 Agenda for Sustainable Development. The right to have access to safe and nutritious food, reaffirmed at the Zero Hunger Challenge launched at Rio+20 at the 2012 Conference on Sustainable Development, implies not only permanent access to food, but also increase in smallholder productivity and income $[1,2]$. As a response to unprecedented population growth, the increasing demand of agricultural and livestock demand transformed the whole channel of food production. The rise of mass farm production transformed the use of the land, impacting the workforce, the environment and threatening the survival of local communities through the global south $[3,4]$. The demand for commodities increases the market value, not necessarily resulting in benefits for the collective. Instead, the food industry mechanization and standardization adds to the unbalance of powers among states. To have a share in the global market, the food industry in the developing economies have to comply with sanitary requirements. Multilateral cooperation to enforce global public health guidelines, initially designed to prevent the spread of epidemics and food intoxication, turned into an asset to boost the rise of the value of commodities subverting the logic of mass food production as a tool to eradicate extreme poverty [5].

Food security, as part of a broad human security agenda, nevertheless, means different challenges for the third world, connecting environmental, health and economic security concerns alike [6-10]. On the opposite side, the food industry constant search for profit radically transformed the uses of the land. The triumph of the genetic engineering and Artificial

Intelligence means rising the productivity while offering less work places. The standardization of agricultural and farm practices though domestic and international regulations enhances sanitary premises dictated by medical and pharmaceutical researches funded in the rich north. As a result, the food industry constant search for profits changes also the dynamic of production itself. By overrating the sanitary regulations to guarantee the security of crops, animal food and livestock, the global health policy for food security overshadows the human, social, economic and environmental cost of massive food production for local communities in the global south [11-14].

\section{The Politics of Food Security for the Global South: Concepts and Challenges}

Post-cold war multilateral cooperation paved the way for the inception of new concepts to reframe the language of international law. The 1993 Vienna Declaration and Program of Action initiate the shift to a human rights oriented perspective: [15-18] 'All human rights are universal, indivisible and interdependent and interrelated. The international community must treat human rights globally in a fair and equal manner, on the same footing, and with the same emphasis. While the significance of national and regional particularities and various historical, cultural and religious backgrounds must be borne in mind, it is the duty of States, regardless of their political, economic and cultural systems, to promote and protect all human rights and fundamental freedoms' [19].

The interdependence of political, civil, social, economic and cultural rights overcomes the previous ideological division that politicized the priority of civil and political rights, from the capitalist side, and the superiority of social, economic and cultural rights from the communist bloc. The universality, 
indivisibility and interdependence, nevertheless, enhance the so-called third generation human rights, informed by the rise of the environmentalist agenda. For the global south, the need to subordinate economic interests to sustainable development threatens to overshadow social rights gains. Fair trade may be the coherent response to avert negative side effects of social and environmental dumping in connection with the spread of outsourcing as a tool to reduce costs and raise revenues to the rich north industry [20-22].

The risk management of costs turns into an asset to attract foreign investment to third world economies [23,24]. Not exclusive to the global south, the Brexit crisis and Trump administration rupture with multilateral trade and environmental agreements suggest similar patterns. The impacts of international politics to the survival of previous legal frameworks to foster global consensus, contributes not only to the erosion of institutional cooperation mechanisms, but also undermining the trust among state and non-state actors.

\section{Global Public Health in the Age of Massive Agriculture and Live Stock Production}

The rise of the value of commodities, such as grains and livestock, increases the weight of developing economies in the global trade [25-28]. To have a share at the market of massive food production, states shall adopt several guidelines to assure the compliance with international regulations [29-33]. The multilateral cooperation among states may be part of a regional integration project, such as the European Union, MERCOSUR and NAFTA [34,35]. Yet, free trade agreements may still be considered a marginal feature of the politics of food security [36]. Massive farm production as an effective tool to fight the fear from hunger, in practice, threatens social and environmental justice in the third world [37,38]. The negative side effects of the expansion of international food systems may threaten the local systems, leading to an exodus of the rural population to urban outskirts $[39,40]$.

The disregard of fair trade as a key instrument to decrease social-economic inequalities land occupation, resulting in the displacement of large populations from the country side to urban centers. The agriculture and livestock sectors occupy vast areas of developing states, especially in South America [41]. The commodities market fuels both the animal food demand for soy beans and corn, and livestock. The concentration of land in the name of massive farm production as such displays also links with modern day slavery, facilitating the allocation of cheap work force to remote areas $[42,43]$.

A closer look at the meaning of massive export for developing economies highlights another side effect of globalization. In some cases, the price to progress also implied corruption, as it is the case of the JBS (a major livestock export conglomerate located in Brazil) involvement at the Car Wash scandal in Brazil $[44,45]$. The experience of Brazil, as a periphery actor within the management of international peace and security, and still a major player in matters of international trade dispute [46,47], sheds a light at some of the many challenges to the very legitimacy of global mechanisms designed to implement fair trade standards in connection with food security imperatives [48-50].

\section{Global Public Health Institutionalized}

The rise of health concerns as a global issue may be founded in the very starting of the international organizations as a channel to promote cooperation to prevent the spread of epidemic diseases across borders. As part of the so-called second generation of human rights, the right to human dignity impacts social and cultural relations under the flag of universalism [5153].

This Universalist perspective reassesses the foundations of state security, to address the security of the human beings. The rise of food security concerns, in this sense, may be considered as a by-product of the human security doctrine that challenges the state-centered sovereignty concept $[54,55]$.

Despite the legacy of the European imperialism, the creation of the International Health Office in 1908 later incorporated by the League of the Nations as a Committees of Health embodies both a continuation and a rupture with the white man civilization project [56].

The United Nations system enlarge the range of international agencies acting to promote international cooperation in several areas connecting not only health concerns, but also its implications for agriculture, social-economic transformation through education and fair trade [57]. The rise of the environmental agenda, nevertheless, shifted the human rights discourse resulting in a reassessment of the relationship between states, individuals, transnational enterprises and NGO's.

To enforce global standards, several UN agencies perform a pivotal role. The World Health Organization, WHO, the Food and Agriculture Organization, FAO, the International Labor Organization, ILO, and the Animal Health International Organization, OIE, advance international agreements and directives to public health guidelines for massive food production [58]. The widespread use of pesticides, antibiotics and hormones in food animals and as diseases prevention to grant standardization of growing livestock still lacks liable sources [59]. The magnitude of the potential harm of medical and pharmaceutical authorized practices to guide the system of massive food production lacks coherent and long-range liable researches $[60,61]$.

\section{Global Public Health and the Politics of Food (in) Security in the Third Word}

The notion of food security in connection of free and fair trade may have pervasive outcomes to third world countries. A universal concept of human security, in practice, reproduces Eurocentric supremacy in a new fashion [62-64]. The digital revolution facilitated the rise of global trade, shifting the power balance between the rich north and the poor south. Yet, the outsourcing of manufacture and the continuing demand for natural resources, such as gas and oil, may be considered only a glimpse of the big picture.

The Breton Woods institutions, such as the IMF, World Bank and GATT, despite the its ideological foundations, entrenched at the premise that international security may not be achieved 
without economic stability, never addressed fair trade. Social and economic rights remained outside capitalist hegemony until the disintegration of the Soviet Union. The possibility of agreement between former rivals paved the way for a paradigm shift to human-rights oriented approach $[65,66]$. The UN 2030 Agenda enhances both food security and fair trade goals as part of the same project. Free trade agreements, though authorized to cooperate with the Universalist human rights agenda, remain outside the UN framework. The creation of the World Trade Organization, also a by-product of the post-cold war transition process, strengthens the role of transnational, aggravating the democratic deficit $[67,68]$. The cross retaliation, as an effective mechanism of enforcement though international channels, often harms the same sector that raised the claim. The state's autonomy to choose to apply subsidies otherwise deemed illegal in other areas considered as more profitable $[69,70]$.

The international trade dispute mechanisms lack of democratic participation reflects the continuation of the statecentered international law [71]. On the opposite side, the development of international criminal law and international legal frameworks granting access to of non-state actors and individuals to international and regional tribunals, strengthen the Universalist conception entrenched at the UN 2030 Agenda [72-74].

\section{Conclusion}

The international politics of food security reflects the permanent tension between liberal and welfare state conceptions. The coexistence of contradictory frameworks to mediate trade disputes and foster sustainable development for the global south unveils some of the major obstacles to enforce a coherent plan of action to end hunger in accordance with fair trade imperatives.

\section{References}

1. Zero Hunger Challenge. Partnering for Nourishing our People, Nurturing our Planet, Growing Prosperity, Harvesting Peace. Sustainable Development. 2012.

2. Zero Hunger Challenge -Transforming our Food System to Transform our World. "The UN Secretary-General's Zero Hunger Challenge launched at Rio +20 called on governments, civil society, faith communities, the private sector, and research institutions to unite to end hunger and eliminate the worst forms of malnutrition.

3. Bachand R. Quatre Strates du Droit International Analysees du Point de Vue des Subalternes, Les Rev. 2011;24:1.

4. Henrique LA, Bizawu SK. Meio ambientee reducao das desigualdades e da pobreza. revista daagu. 2017 Sep 29;16(03):197-216.

5. Transforming our world: The 2030 Agenda for Sustainable Development. Resolution adopted by the General Assembly on 25 September 2015. 2015; A/RES/70/1.

6. Gasper D, Gómez O. Evolution of thinking and research on human security and personal security 1994-2013.

7. https://www.un.org/humansecurity/
8. Human Security: A stronger framework for a more secure future. Human Development Reports. UNDP. 10 June 2015 TEITEL, Ruti. Humanity's Law. New York: OUP. 2016.

9. Lee RP. The politics of international agri-food policy: Discourses of trade-oriented food security and food sovereignty. Environmental Politics. 2013 Mar 1;22(2):21634.

10. Rocha C. Food insecurity as market failure: a contribution from economics. Journal of Hunger \& Environmental Nutrition. 2007 Sep 21;1(4):5-22.

11. Pibulsonggram N, Amorim C, Douste-Blazy $\mathrm{P}$, et al. Oslo Ministerial Declaration-global health: A pressing foreign policy issue of our time. Lancet. 2007 Apr 21;369(9570):1373-8

12. Boyd W. Making meat: Science, technology, and American poultry production. Technology and Culture. 2001 Oct 1;42(4):631-64.

13. Jarosz L. Defining world hunger: Scale and neoliberal ideology in international food security policy discourse. Food, Culture \& Society. 2011 Mar 1;14(1):117-39.

14. Bereuter D, Glickman D. Healthy food for a healthy world: Leveraging agriculture and food to improve global nutrition. Chicago: Chicago Council on Global Affairs. 2015 Nov.

15. Kadiyala S, Harris J, Headey D, et al. Agriculture and nutrition in India: Mapping evidence to pathways. Annals of the New York Academy of Sciences. 2014 Dec 1;1331(1):4356.

16. Reardon T, Barrett CB, Berdegué JA, et al. Agrifood industry transformation and small farmers in developing countries. World development. 2009 Nov 1;37(11):1717-27.

17. Wittman H, editor. Food sovereignty: Reconnecting food, nature \& community. Pambazuka; 2010.

18. Vienna Declaration and Programme of Action. Adopted by the World Conference on Human Rights in Vienna on 25 June 1993;1-20.

19. https://www.ohchr.org/Documents/ProfessionalInterest/ vienna.pdf

20. Babin R, Nicholson B. How green is my outsourcer? Measuring sustainability in global IT outsourcing. Strategic Outsourcing: An International Journal. 2011 Feb 22;4(1):47-66.

21. Delpech Q. Une extension du domaine de la lutte: l'internationalisation des savoir-faire syndicaux américains en Amérique centrale. Critique internationale. 2014(3):3346.

22. Rowthorn R. The impact on advanced economies of northsouth trade in manufacturing and services. Brazilian Journal of Political Economy. 2005 Apr;25(2):60-73.

23. Fairbairn M. Framing transformation: the counterhegemonic potential of food sovereignty in the US context. Agriculture and Human Values. 2012 Jun 1;29(2):217-30. 
Citation: Waisberg T. The international politics of food security: How to conciliate global health guidelines for massive food production with fair trade in the third world? J pub health catalog. 2018;1(3):10-14.

24. Breilh J. Aceleración agroindustrial: Peligros de la nueva ruralidad del capital.

25. Doyal L, Pennell I. The political economy of health. Pluto Press; 1979.

26. Horton R. Health as an instrument of foreign policy. The Lancet. 2007 Mar 10;369(9564):806-7.

27. Hospes O. Food sovereignty: the debate, the deadlock, and a suggested detour. Agriculture and Human Values. 2014 Mar 1;31(1):119-30.

28. Jarosz L. Comparing food security and food sovereignty discourses. Dialogues in Human Geography. 2014 Jul;4(2):168-81.

29. Falcon WP, Naylor RL. Rethinking food security for the twenty-first century. American Journal of Agricultural Economics. 2005 Dec 1;87(5):1113-27.

30. Food and Agriculture Organization Of The United Nations. Trade reforms and food security: Conceptualizing the linkages. Food \& Agriculture Organi; 2005.

31. Bizawu K, de Paiva Toledo A, Lopes LC. Economic sustainability and the world trade organization: The global ethical crisis on relations between states. Veredas do Direito: Environmental Law and Sustainable Development. 2017 Dec 18; 14 (30): 99-116.

32. Paarlberg R. Food Politics: What Everyone Needs to Know ${ }^{\circledR}$. Oxford University Press; 2013 Aug 26.

33. Beuchelt TD, Virchow D. Food sovereignty or the human right to adequate food: Which concept serves better as international development policy for global hunger and poverty reduction?. Agriculture and Human Values. 2012 Jun 1;29(2):259-73.

34. FAO. The state of food insecurity in the world. Food and Agriculture Organization of the United Nations, 2013.

35. Ramina L. TWAIL-Third World Approaches to International Law and Human Rights: Some Considerations. Revista de Investigações Constitucionais. 2018;5:261.

36. Paarlberg R. Food politics: What everyone needs to know. 2 ed, NY: OUP, 2013.

37. Beuchelt TD, Virchow D. Food sovereignty or the human right to adequate food: which concept serves better as international development policy for global hunger and poverty reduction? Agriculture and Human Values. 2012 Jun 1;29(2):259-73.

38. Ramina L. TWAIL-Third World Approaches to International Law and Human Rights: Some Considerations. Revista de Investigações Constitucionais. 2018;5:261.

39. Jones AD, Ejeta G. A new global agenda for nutrition and health: The importance of agriculture and food systems. Bulletin of the World Health Organization. 2016 Mar $1 ; 94(3): 228$.

40. Gundersen C. Food Insecurity Is an Ongoing National
Concern- Advances in Nutrition. 2013 Jan 4;4(1):36-41.

41. Meszaros G. Taking the land into their hands: The landless workers' movement and the Brazilian state. Journal of Law and Society. $2000 \mathrm{Dec} ; 27(4): 517-41$.

42.http://www.itamaraty.gov.br/images/Banco_de_imagens/ Sentenca_Fazenda_Brasil_Verde.pdf

43. Feliciano GG, Conforti PL. The case of the enslaved at Fazenda Brasil Verde. 2017.

44. BBC News. Brazil meat-packing giant JBS to pay record \$3.2bn corruption fine. May 31, 2017. Available at: https:// www.bbc.com/news/world-latin-america-40109232

45. Felter C, Labrador RC. Brazil's Corruption Fallout. Federal investigators in Brazil have uncovered corruption at the highest levels of the government and in the country's largest corporations. Council of Foreign Relations. April 24, 2018.

46. Afionis S, Stringer LC, Favretto N, et al. Unpacking Brazil's leadership in the global biofuels arena: Brazilian ethanol diplomacy in Africa. Global Environmental Politics. 2016 Aug;16(3):127-50.

47. Amaral WA, Peduto A. Food security: The Brazilian case. Series on Trade and Food Security Policy Report. International Institute for Sustainable Development. Winnipeg, Canada. 2010.

48. Alkon AH, Mares TM. Food sovereignty in US food movements: Radical visions and neoliberal constraints. Agriculture and Human Values. 2012 Sep 1;29(3):347-59.

49. Allen P. Mining for justice in the food system: Perceptions, practices, and possibilities. Agriculture and Human Values. 2008 Jun 1;25(2):157-61.

50. Bell-Sheeter A. Food sovereignty assessment tool.2004.

51. Pahuja S. Decolonising international law: Development, economic growth and the politics of universality. Cambridge University Press; 2011 Sep 29.

52. Prakash G, editor. After colonialism: imperial histories and postcolonial displacements. Princeton University Press; 1994 Nov 29.

53. Rocha C, Liberato RS. Food sovereignty for cultural food security: The case of an indigenous community in Brazil. Food, Culture \& Society. 2013 Dec 1;16(4):589-602.

54. Lyons K. Urban food advocates' tactics to rebuild food systems: Convergence and divergence in food security and food sovereignty discourses. Dialogues in Human Geography. 2014 Jul;4(2):212-7.

55. Pimbert MP. Towards food sovereignty: Reclaiming autonomous food systems. International institute for environment and development (IIED); 2008 Dec.

56. Borowy I. Coming to terms with world health: the League of Nations Health Organisation 1921-1946. Peter Lang; 2009.

57. Lang T. Food control or food democracy? Re-engaging 
nutrition with society and the environment. Public health nutrition. 2005 Sep;8(6a):730-7.

58. Nestle M. Food politics: How the food industry influences nutrition and health. Univ of California Press; 2013 May 14.

59. European Centre for Disease Prevention and Control, European Food Safety Authority, European Medicines Agency. ECDC/EFSA/EMA first joint report on the integrated analysis of the consumption of antimicrobial agents and occurrence of antimicrobial resistance in bacteria from humans and food $\square$ producing animals. EFSA Journal. 2015 Jan;13(1):4006.

60. Chan M. Combat drug resistance: no action today means no cure tomorrow. World Health Organization. 2011.

61. Landers TF, Cohen B, Wittum TE, et al. A review of antibiotic use in food animals: Perspective, policy, and potential. Public health reports. 2012 Jan;127(1):4-22.

62. Gross A. After the Falls: International Law between Postmodernity and Anti-Modernity.

63. Jouannet E, Ruiz FH, Sorel JM. Regards d'une génération sur le droit international. Pedone; 2008.

64. Krisch N. International law in times of hegemony: Unequal power and the shaping of the international legal order. European Journal of International Law. 2005 Jun $1 ; 16(3): 369-408$.

65. Nye Jr SJ. Understanding International Conflicts: An Introduction to Theory and Conflicts.
66. Martin M, Bojicic-Dzelilovic V. 'It's not just the economy, stupid'. The multi-directional security effects of the private sector in post-conflict reconstruction. Conflict, security \& development. 2017 Jul 4;17(4):361-80.

67. Howse R. How to Begin to Think about the 'Democratic Deficit'at the WTO. International Economic Governance and Non-Economic Concerns. 2003:79-101.

68. Joseph S. Blame it on the WTO? A Human Rights Critique. OUP, 2011.

69. Barral W, Amaral R. Fim do contencioso do algodão: Lições de uma disputa na OMC. RBCE - FUNCEX, 122, 2015.

70. ICTSD. WTO Panel Allows Brazil to Cross-Retaliate on IP, Services in U.S. Cotton Row. International Center for Trade and Sustainable Development. September 9, 2009.

71. Duplessis I. Does International Law Have a Colonial Flavor - The Heritage of Multilateral International Institutions, The. RJT ns. 2007;42:311.

72. Bassiouni MC. International Recognition of Victims' Rights. Human Rights Law Review. 2006 Jan 1;6(2):203-79.

73. Cavallaro JL. Toward Fair Play: a decade of transformation and resistance in international human rights advocacy in Brazil. Chi. J. Int'l L.. 2002;3:481.

74. http://www.undp.org/content/undp/en/home/sustainabledevelopment-goals.html

\section{*Correspondence to:}

Waisberg T

Adjunct Professor

Dom Helder College

Brazil

E-mail: tatianawaisberg@gmail.com 